Article

\title{
Bank Regulation in Dollarized Economies: The Case of Turkey
}

Erick W. Rengifo ${ }^{1}$, Emre Ozsoz ${ }^{2, *}$, Mustapha A. Akinkunmi ${ }^{3}$ and Eduardo Court ${ }^{4}$

${ }^{1}$ Center for International Policy Studies, Economics Department, Fordham University, 441 E. Fordham Rd., Bronx, NY 10458, USA; E-Mail: rengifomina@ fordham.edu

${ }^{2}$ Social Studies Department, School of Liberal Arts, SUNY-FIT, 227 W 27th Street, NY 10001, USA

${ }^{3}$ Brickfield Road Associates, 8 Onikoyi Street, Parkview Estate, Ikoyi, Lagos 101233 , Nigeria; E-Mail: abbie@bra-limited.com

${ }^{4}$ Centrum Católica, Daniel Aloma Robles 125, Los Alamos de Monterrico Surco, Lima 33, Peru; E-Mail: ecourt@pucp.edu.pe

* Author to whom correspondence should be addressed; E-Mail: emre_ozsoz@ fitnyc.edu; Tel.:+1-212-217-4979.

Received: 16 September 2013; in revised form: 17 October 2013 / Accepted: 30 October 2013 / Published: 13 November 2013

\begin{abstract}
Regulators in emerging markets are increasingly curtailing the practice of foreign currency lending. In such a move Turkish regulatory authorities banned foreign currency lending to households in 2009. This paper examines the evolution of financial dollarization in Turkey in the 2002-2009 period by looking the currency composition of loans and deposits in the banking system and the macroeconomic developments. We find that the Turkish banking system was unhedged against currency fluctuations and the regulators acted preemptively in banning the practice.
\end{abstract}

Keywords: dollarization; banking regulation; Turkish banking system

\section{Introduction}

A common phenomenon in emerging markets is currency substitution and, consequently, foreign currency lending. Known as dollarization, the process refers to the use of a currency other than the country's own in place of or in addition to the local currency. The practice had been encouraged by governments in these economies for its positive impacts, and regulators had taken steps enabling citizens to open savings accounts, as well as borrowing in foreign currency. However, recently, we 
have observed that many emerging market economies have moved away from the practice: regulators in Hungary, Latvia and Poland have tightened eligibility requirements for borrowing in foreign currency and have encouraged banks to use moral suasion to deter retail level foreign currency (FC) borrowing. The authorities in these countries required banks to disclose the exchange rate risks of foreign currency loans to their clients. In countries like Croatia, Kazakhstan and Romania, stronger provisioning requirements were also imposed on foreign currency lending Brown and Haas [1]. Ukraine completely banned FC lending to households in late 2008. In 2011, the Korean government banned banks and other financial institutions from investing in foreign-currency denominated bonds ("Kimchi Bonds") that were used for conversion into local currency by Korean companies who needed foreign currency financing. Other countries that have taken measures to restrict the growth of foreign currency loans in 2011 include Angola, Belarus and Serbia.

Turkey, where households and business had been able to borrow in foreign currency for many years, followed in the footsteps and banned all household borrowing in foreign currency in June, 2009, while enabling businesses to continue to keep their foreign currency lines of credit open. The Central Bank of the Republic of Turkey (CBRT) did not provide any justification as to why the practice was ended in its decision statement. (Article 17 of the Decree 32 titled "Turk Parasini Koruma Kanunu”, issued by the Council of Ministers on 16 June 2009).

The aim of this paper is to reflect on the period during which foreign currency borrowing had been a widespread practice in Turkey and, secondly, to point to changes in fundamental economic and banking indicators as a result of the practice. By doing so, we hope to shed light on the circumstances that led to the policy changes in Turkey in 2009. We believe our conclusions are universal in the sense that they explain the policy reversal in many other countries mentioned above around the same time period.

Previously, many economic studies focused on the reasons for foreign currency borrowing or saving in a foreign currency in these economies. Among the many answers, the following theories stand out: The Currency Substitution Hypothesis, Minimum Variance Portfolio Theory (MVP) and the institutional view.

The Currency Substitution Theory links the erosion of money's function as a store of value to increased rates of saving and credit dollarization (for more on the Currency Substitution Hypothesis, see the surveys by Calvo and Vegh [2], Savastano [3] and Giovannini and Turtelboom [4]). Most high inflation countries also had high rates of foreign currency saving and lending, which support the theory.

The Minimum Variance Portfolio (MVP) Hypothesis developed by Levy-Yeyati [5] and Ize and Levy-Yeyati [6] focuses on the relative volatility of returns to financial assets in local and foreign currency. In this model, dollarization is driven by the volatility of inflation and real exchange rate depreciation, rather than the expected inflation and nominal depreciation. The domestic interest rate is determined according to an interest parity condition that is not related to the degree of financial dollarization in the country. Thus, for a given variance of inflation, an increase in the variance of the rate of depreciation reduces dollarization by limiting the hedging benefits of dollar assets. One important implication of this model is that it suggests that financial dollarization will persist as long as inflation volatility remains high in relation to exchange rate volatility, even under low inflation. Among those who tested their theory, Basso et al. [7] demonstrated that in the case of 24 transition economies, interest rate differentials were the main drivers of the dollarization of both loans and deposits in the banking system. 
A third and a final perspective on the causes of dollarization is the institutional view set forth mainly by Levy-Yeyati [5]. This framework suggests that lack of credibility in the country's institutions can easily lead depositors to continue saving in foreign currency. Furthermore, according to the institutional view, banks may continue to lend in foreign currency, even after the price level has been stabilized [5]. There is evidence to validate this theory. For example, Neanidis and Savva [8] showed that institutional quality influences short-run dollarization decisions by banks.

The reasons that lead to dollarization of savings and credit in a country's banking system are important. Equally important is the foreign currency risk caused by such heavy foreign currency exposure of the banking system. From a bank's perspective dollarization has two aspects: not only do depositors open their accounts in a foreign currency but also provides incentives to more and more borrowers to apply for foreign currency loans. Therefore theoretical and empirical studies highlighting the consequences of the double exposure on a country's banking system are needed to fully understand the dollarization phenomenon. Unfortunately, there are not many theoretical studies on the impact of dollarization on a country's banking system. Among the first to empirical papers that deal with this link are De Nicolo et al. [9] ${ }^{1}$. They point out to the transformation of the exchange rate risk in the banking system resulting from the foreign currency denomination of deposits and loans into another form, the default risk through increased defaults by borrowers who borrow in foreign currency. Among other economists who draw attention to the same phenomenon is Calvo [10]. Empirical evidence suggests that this is a wide spread practice in the banking systems of dollarized economies. Luca and Petrova [11] used an optimal portfolio allocation model to analyze this practice in transition economies and showed that banks once exposed to foreign currency risk through accumulation of dollar liabilities shift this risk onto their corporate customers by lending in foreign currency. This increases the exposure of the economy to currency and financial crisis even in the presence of deep and liquid forward foreign exchange markets. Yet, it appears that banks are aware of the transformation of the risk and thus position themselves accordingly by increasing loan loss provisioning which thus decreases their profitability. Ozsoz [12] and Kutan et al. [13] have provided evidence of this phenomenon by demonstrating that banks in dollarized economies have lower profitability and behave more risk averse as a consequence of this risk.

Increased loan default risk as a consequence of foreign currency lending or increased loan loss provisioning and thus lower profitability in the banking system are reasons alone for us to evaluate the dollarization process in emerging market economies. Afterall, we know how common banking crises are in emerging market economies. Moreover recent history has shown us that financial difficulties arising in the banking sector can lead to a general recession or might have spillover effects in non-financial sectors as well (see Setser et al. [14]). The actions taken by governments in these countries can result in regulators' risk mitigation efforts in their banking systems. Therefore studying the development of foreign currency lending in Turkey in the period prior to the regulatory change can give us some ideas about regulatory behavior and risk in other emerging market economies. The fact that other emerging

1 De Nicolo et al. [9] also point out the lack of a theoretical framework or empirical literature on this issue. 
market economies (i.e., Korea) restricted their FC lending also suggests that the findings of this paper may have implications beyond the scope of one country.

In the following section we provide a detailed analysis of macroeconomic developments in Turkey within the last decade that can help us understand the causes of the regulatory switch, we also provide a discussion on these developments and their implications in the subsections; Section 3 concludes.

\section{The Macroeconomic Picture in Turkey and Its Impact on Foreign Currency Lending}

This section provides a brief description of the relevant macroeconomic developments in Turkey in the run up to the regulatory change in 2009 . We highlight the changes in economic variables that influenced the evolution of dollarization in Turkey during the 2002-2009 period.

Figure 1 presents the ratio of FC loans to total loans. As can be clearly seen, foreign currency loans have constituted a big portion of loan portfolios in Turkey for banks. FC loans accounted for 54\% of the total money lent in Turkey at the end of 2002 and for 27\% in 2009 (the minimum value of this ratio was $3 \%$ for Ziraat Bank in the second quarter of 2009, and the maximum was $85 \%$ for Finansbank in the first quarter of 2003.) Although the ratio falls in 2002 and in 2006, it returns to the average levels of around $28 \%$ afterwards. This means one-fourth of all loans in the banking system were in foreign currency denomination as we reach the end of 2006.

Figure 1. Foreign currency (FC) loans to total loan portfolio in the Turkish banking system.

FC Loans to Total Loan Ratio

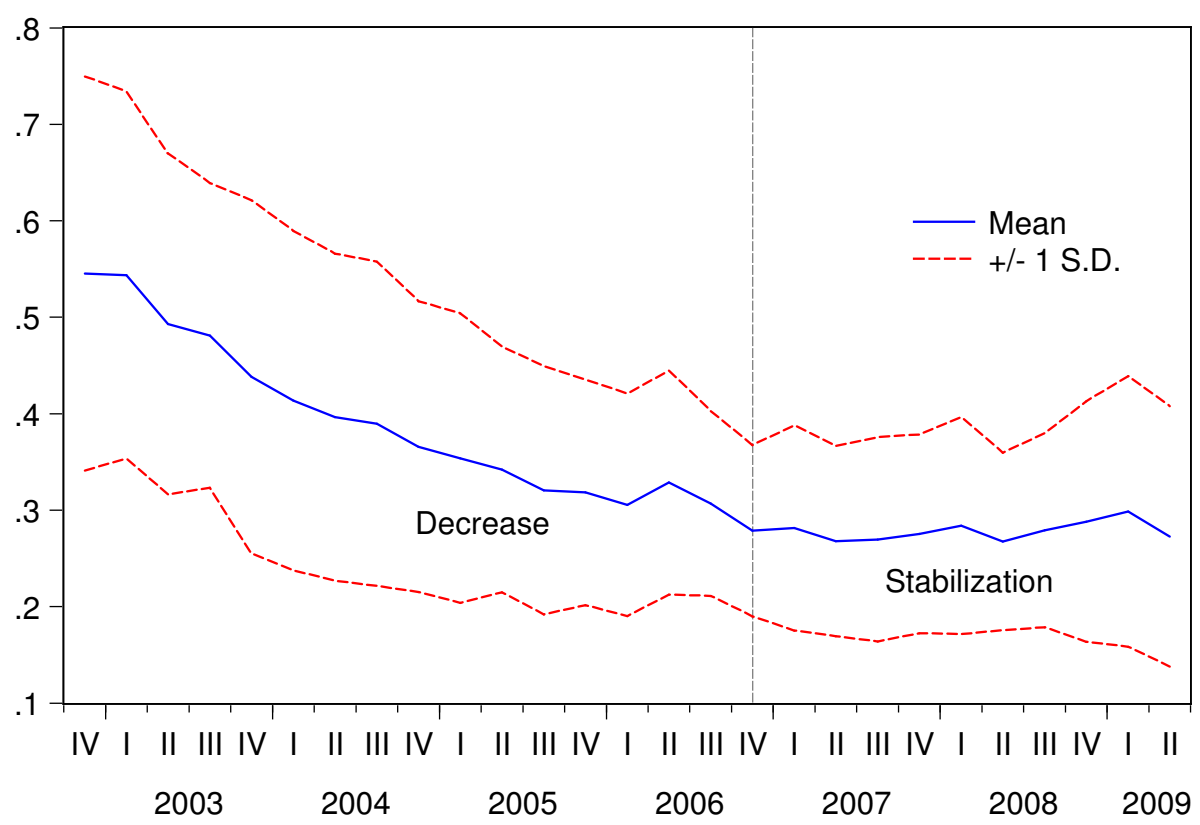

The figure shows the average ratio of foreign currency denominated loans to the banks' overall loan portfolio in our sample with $+1 /-1$ standard deviation bounds. The figure covers the fourth quarter of 2002 until the second quarter of 2009.

Figure 2 presents the foreign currency loan ratios for the the five largest (in terms of assets) non-state owned banks in our sample as of the second quarter of 2009, which is the last quarter before the regulators banned foreign currency lending to households (as of 2009, these five banks represented over 56\% of all 
assets in the Turkish banking system.) As the figure makes it perfectly clear, all non-state owned banks at the end of the sample period have had foreign currency denominated loans close to $28 \%$ of their total loan portfolios. Such heavy exposure to foreign currency lending must have obviously been a cause for concern to regulators and may shed light on the reasons behind the policy change.

Figure 2. FC loans to total loan portfolio for the largest non-state banks.
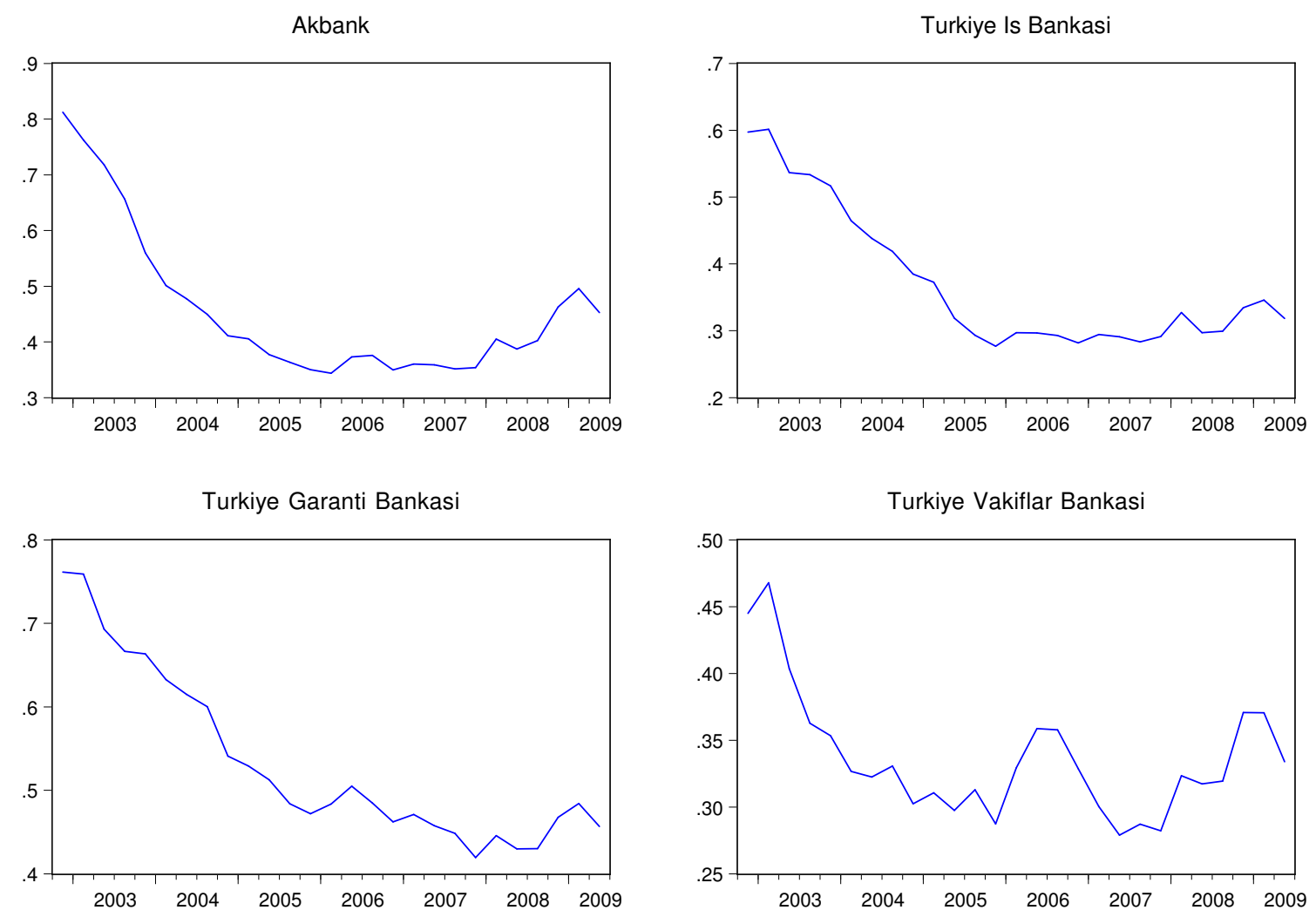

Yapi ve Kredi Bankasi

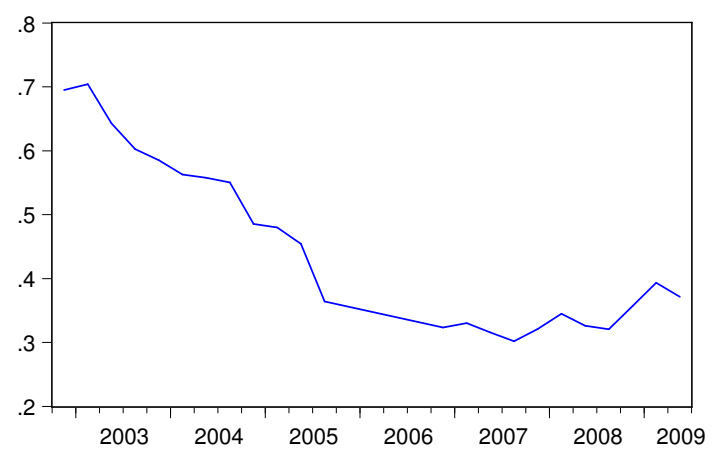

The figure shows the ratio of foreign currency-denominated loans to overall loan portfolios of the largest non-state owned banks in our sample. The figure covers the fourth quarter of 2002 until the second quarter of 2009.

In Figure 3, we can see the time series of the aggregated loans in foreign currency and in Turkish lira. The figure shows that the foreign currency loans had a faster pace of growth than Turkish lira loans, starting at around 2004. Prior to this date, it is clear that growth in foreign currency loans was higher. Regardless of the currency denomination, we can see that both loans grew at a rapid pace in Turkey. 
Figure 3. Foreign currency and Turkish lira loans adjusted for inflation.

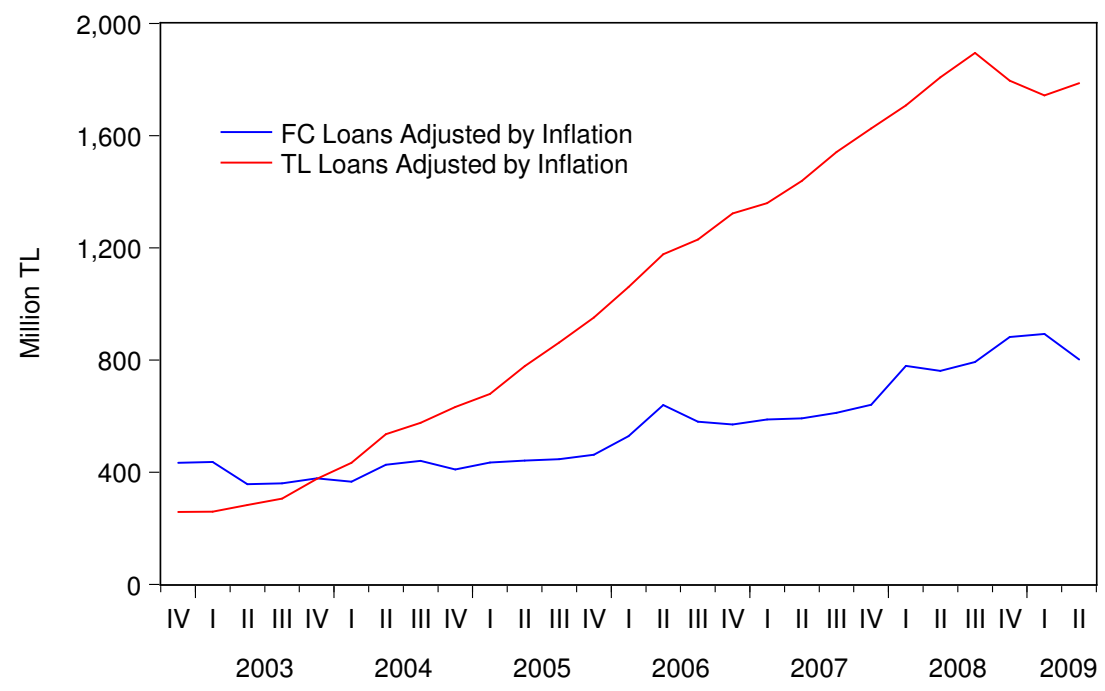

The figure shows the level of foreign currency and Turkish lira denominated loans extended by the banks in our sample during the study period. Both series are in terms of millions of Turkish liras and are adjusted for inflation. The figure covers the period from the fourth quarter of 2002 until the second quarter of 2009.

\subsection{Inflation Stabilization and Its Impact on FC Loans}

Turkish regulators started to follow an implicit inflation targeting (IT) regime since 2002, and since 2006, the Turkish Central Bank fully committed to the policy (according to the Monetary and Exchange Rate Policy report for 2007, Turkey adopted the inflation targeting regime formally at the turn of 2006.) During this period, the inflation rate decreased from $45 \%$ to $10 \%$.

Figure 4. Inflation $v s$. FC to TLloan ratio.

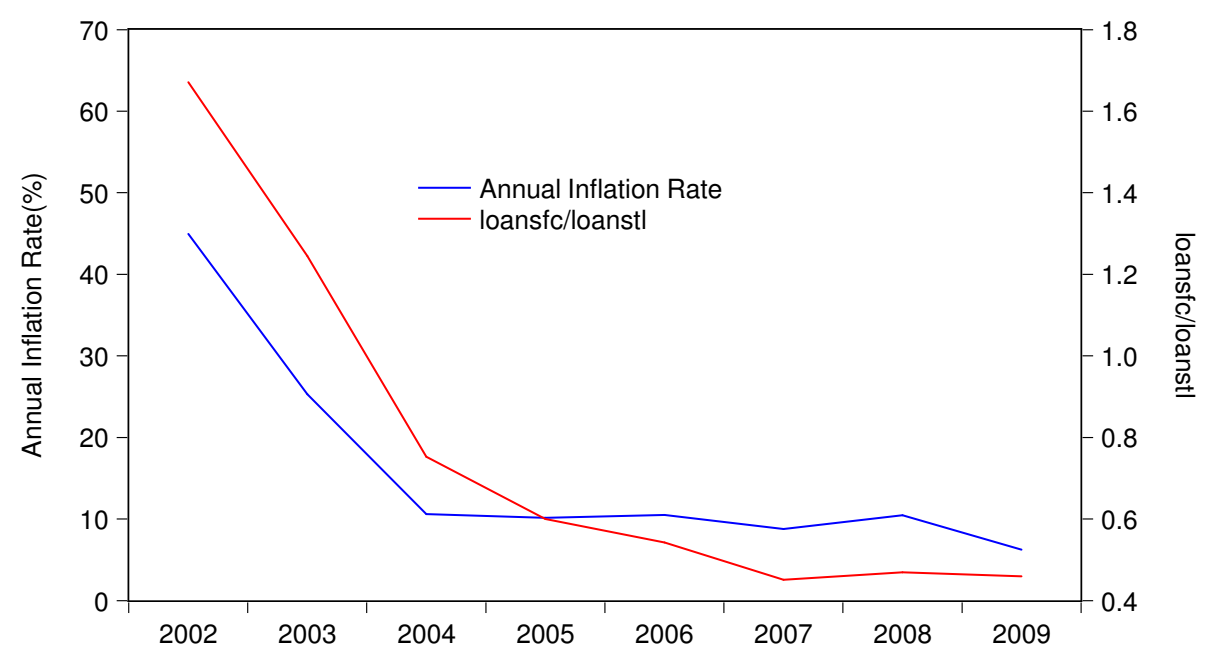

This figure presents Turkey's annual inflation rate (left scale) and the ratio of loans in FC to loans in Turkish lira (right scale) for the period of 2002, Q4, to 2009, Q2. Source: Turkish Banks Association and Central Bank of the Republic of Turkey (CBRT).

In Figure 4, we can see the ratio of foreign currency loans to loans in local currency and the inflation rate in Turkey between 2002 and 2009. It can be inferred from the picture that inflation is highly correlated with the currency structure of the banks' loans. As inflation came under control and started to decrease (see Figure 1), the Turkish lira denominated loan growth increased at a higher 
pace than that of foreign currency loans. One of the theories explaining the causes of the dollarization phenomenon, namely the Currency Substitution Hypothesis, suggests that the main cause of dollarization in an economy is the high inflation rate. As seen in the Turkish case, as inflation fell for the period under study, banks and borrowers preferred to borrow in local currency as opposed to foreign currency. It is also apparent that households and firms also started saving more in the local currency as a result of falling inflation: the correlation coefficient between inflation and the ratio of foreign currency deposits to total deposits is $58.3 \%$, and the correlation between inflation and loans in foreign currency is $62 \%$.

\subsection{Economic Growth and its Impact}

Between 2002 and 2009, Turkey has maintained an annual average GDP growth rate of $4.57 \%$ despite a contraction of $6.05 \%$ in 2009. Turkish export volume increased 60\% between January 2003 and June 2009. The foreign direct investment (FDI) flows into the country increased from less than 1 billion US Dollars in 2002 ( $0.46 \%$ of GDP) to over 6.8 billion US dollars (1.2\% of GDP) in 2009.

The time series of these variables can be seen in Figure 5.

Figure 5. FDI and Private Capital Flows vs. Exports.

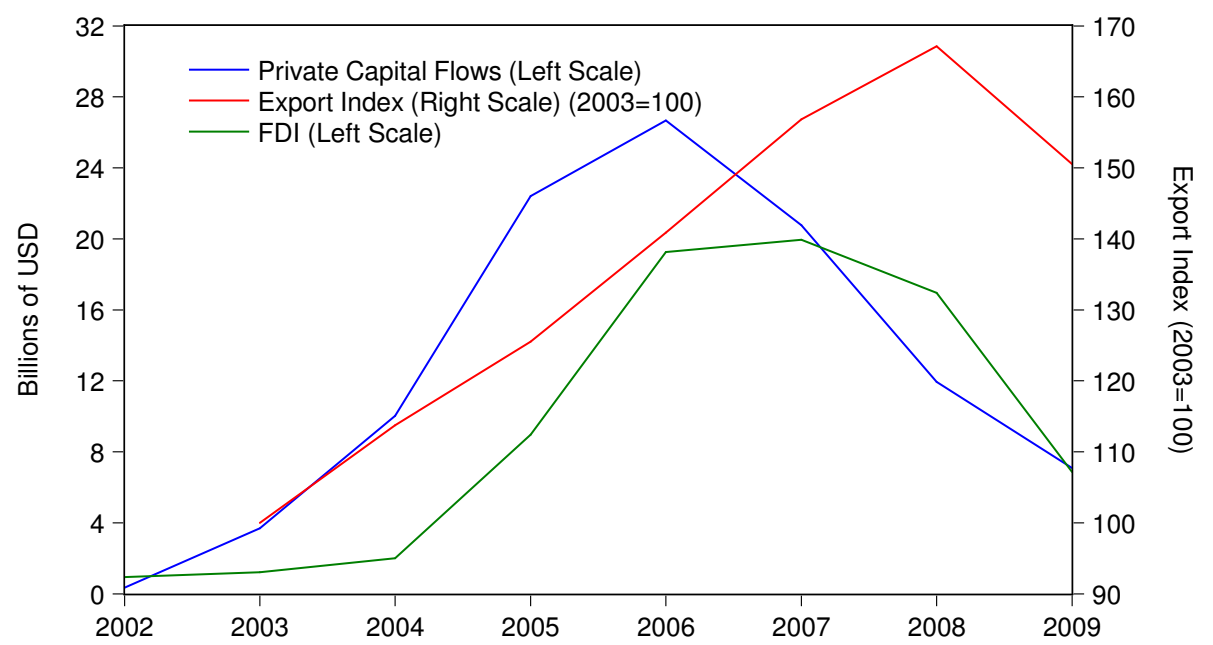

The figure above shows the foreign Trade export volume index for Turkey $(2003=100)$ against Private Capital Flows and FDI between 2002 and 2009. Private Capital Flows and FDI Data are in billions of Turkish Liras. Source: TURKSTAT \& World Bank.

Although Turkey suffered from the Global Financial Crisis and its impact on falling demand from its traditional markets such as Europe, manufacturing grew at an average rate of $4.7 \%$ between 2002 and 2009. The gross capital formation during the same time frame grew at an average $7.6 \%$ despite the Global Financial Crisis. Although the unemployment rate has hovered around $10 \%-11 \%$ and the labor force participation rate has not changed significantly (around 49\%) during our study period, Turkey has achieved a phenomenal growth in its income levels. The GNI per capita has increased from $\$ 3460$ in 2002 to over $\$ 9000$ in 2009 , while the percentage of population earning less than $\$ 2 /$ day has decreased by half from $9.57 \%$ in 2002 to $4.16 \%$ in 2009 . Table 1 provides additional economic indicators for Turkey. 
Table 1. Turkish Economic Indicators.

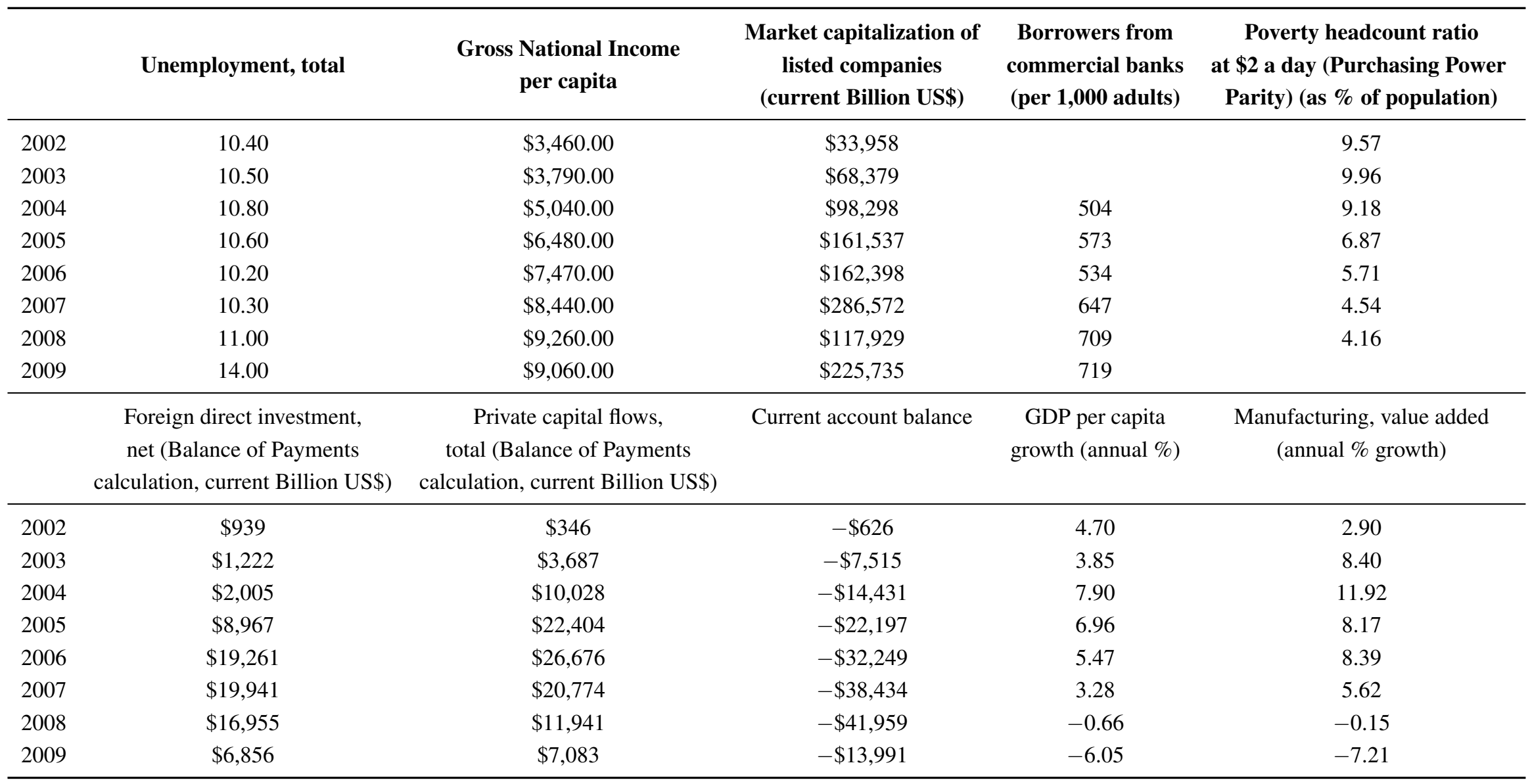

This table presents time series information about key economic indicators in Turkey. Unemployment rate is in \% of total labor force; Gross National Income per capita is calculated using Atlas method and is in current USD; Market capitalization of listed companies, Current Account Balance, Foreign direct investment and Private capital flows are in terms of current USD, Source: World Bank. 
We expect to see a positive loan growth in any country not just Turkey under such growth. Figure 6 shows the time series of the real GDP and the levels of loans in Turkish Lira and in other currencies. There is a high correlation between GDP and the two series: The correlation coefficient between the real GDP and the Turkish Lira denominated loans for the whole study period is 0.98 while the same ratio is equal to 0.96 with respect to loans in foreign currency.

Figure 6. GDP vs. Loans in TL and Foreign Currency.

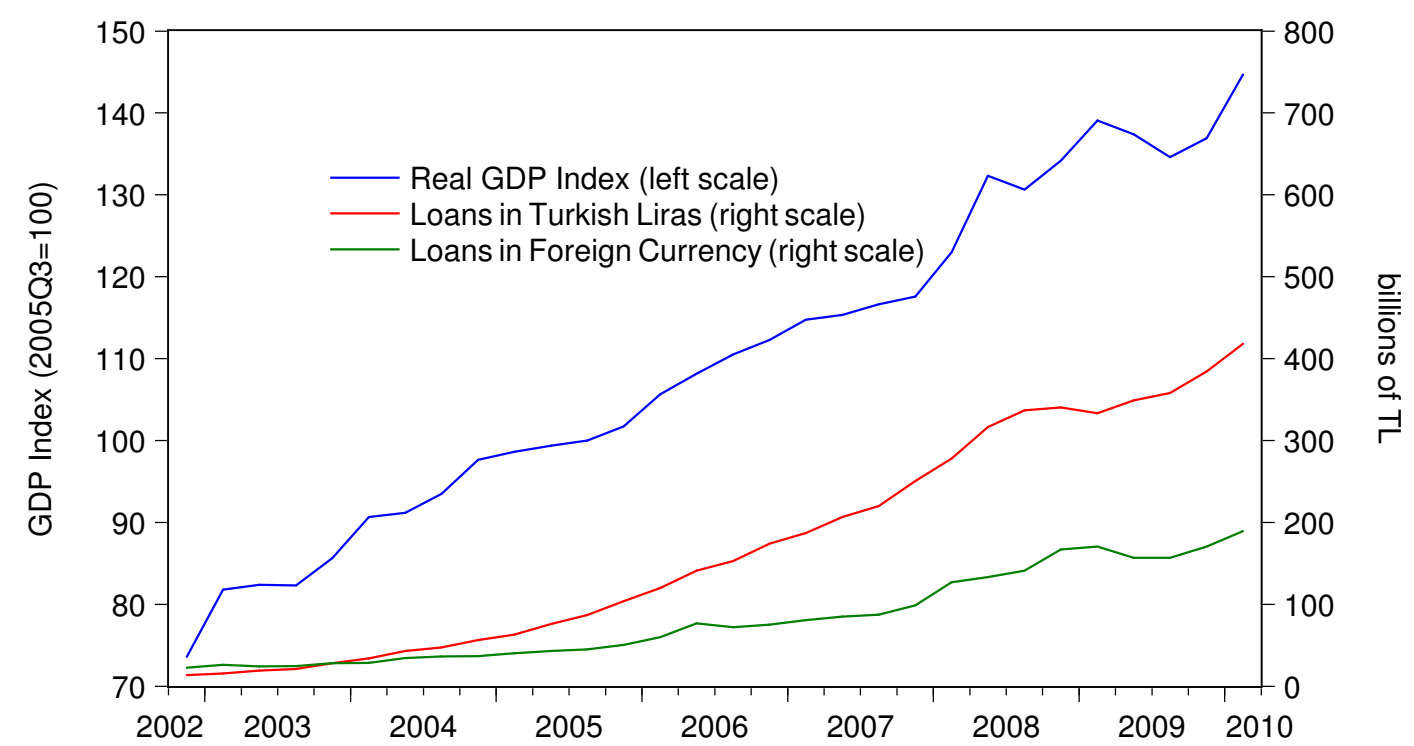

The figure above represents the level of Turkish real gdp(gdpreal) against total Turkish lira(loanstl) and the foreign currency $($ loans $f$ c) denominated loans extended by the banks in our sample during our study period. All values are in terms of billions of Turkish Liras and adjusted for inflation.

\subsection{Dynamics of Local Currency}

We also need to evaluate the exchange rate to better understand dollarization and its evolution in Turkey. After the banking crisis of 2001-2002, Turkey ended its basket regime and floated the lira. Following the float announcement, we observed that the lira appreciated continually during the period of our study. There were only two exceptions to the appreciation: spring of 2006, which corresponds to the emerging market sell-off, and the fall of 2008, which corresponds to the onset of the Global Financial Crisis with the fall of the Lehman Brothers in the US.

The emerging market sell-off that took place in the spring of 2006 caused an almost $30 \%$ depreciation of the lira, prompting the CBRT to intervene in the foreign exchange market repeatedly during the months of May and June (See Figure 7). Other emerging economies, such as Brazil and India were also affected by the emerging market sell-off of 2006. According to CBRT's Monetary and Exchange Rate Policy report for 2007, on June 13 and 23, 2006, the Central Bank decided to directly intervene in the market by selling foreign currency in order to prevent the excessive volatility observed in line with the liquidity shortage in the foreign currency market due to global liquidity conditions. The total amounts sold were USD 0.5 billion and USD 0.8 billion, respectively. There were two additional interventions, during which the CBRT sold an additional one billion dollars worth of foreign currency. However, by the end of the same year, the lira recovered its losses $v s$. other currencies, and by 2007, it appreciated 
to its record highs $v s$. the dollar. The positive investor mood surrounding the general elections in July of 2007 was instrumental in this reversal (The Turkish lira returned to its appreciation trend as a result of capital inflows prior to the general election at the end of July 2007, in which the ruling Aydinlik ve Kalkinma Party (AK Party) received $46 \%$ of the vote and a majority in the parliament.)

Figure 7. Turkish lira to USD exchange rate.

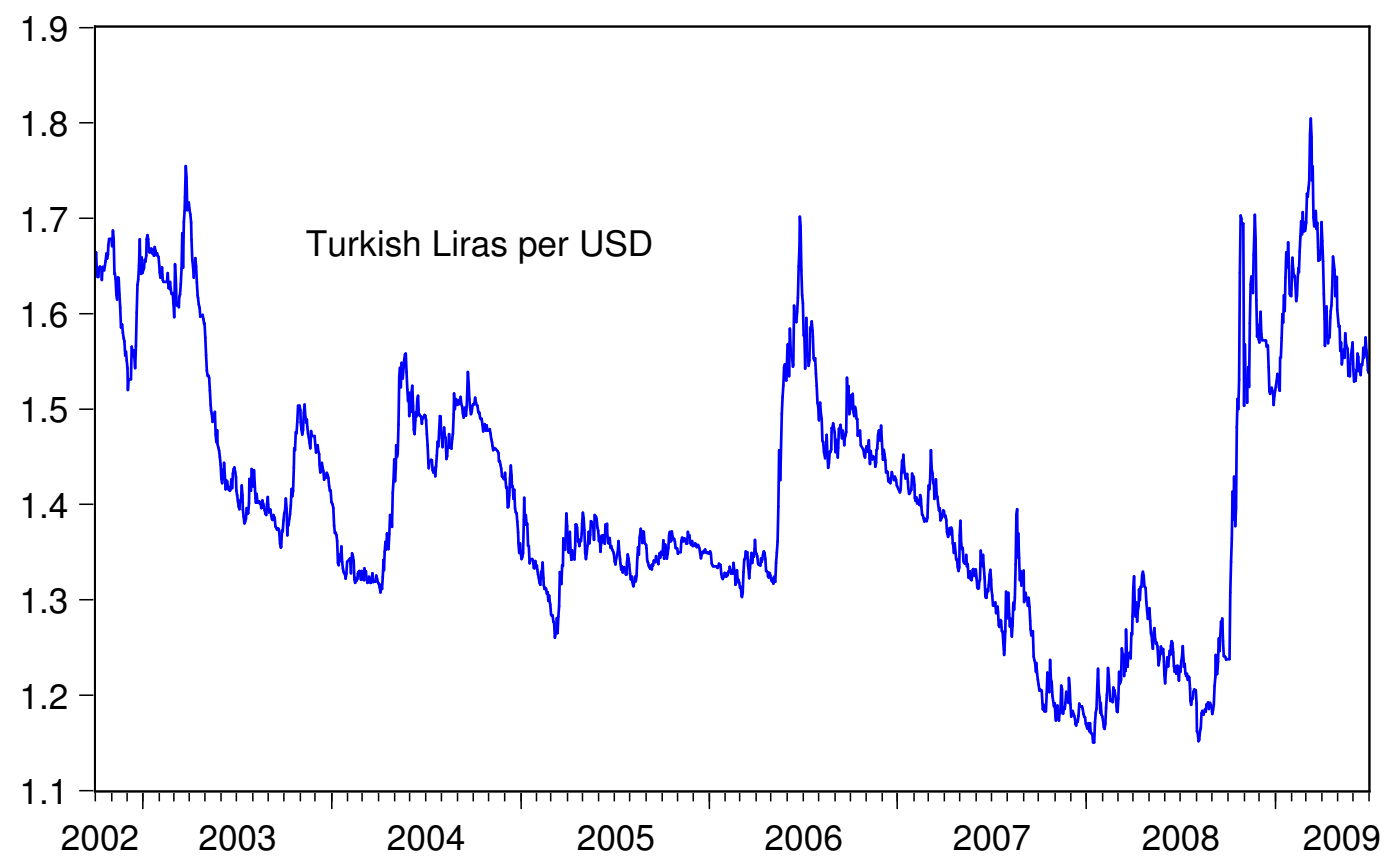

The figure above shows the daily exchange rates between the Turkish lira and the USD during our study period. The vertical scale represents Turkish liras per USD.

The Global Financial Crisis in the third quarter of 2008 brought with it sudden portfolio reversals from all emerging markets, causing depreciation of the local currencies. The lira-USD exchange rate went up from 1.15 TLper USD in the first week of August 2008 to over 1.69 TL per USD in the last week of October 2008 as shown in Figure 7. This sharp increase in such a short period is directly the outcome of crisis. The exchange rate stabilized as the effects of the crisis faded over time, and by the end of our study period (June 2009) the lira/USD had stabilized in the 1.5-1.6 TL/USD range. Economic management by the Turkish Central Bank was instrumental in this stabilization.

Turkish banks held 31.2 billion liras worth of foreign currency loans on their portfolios in 2002, this number tripled to over 100 billion lira as we approached 2009. When the regulators banned household loans, the total amount of foreign currency loans in the banking system was 112 billion TL. Part of this increase can be explained by borrowers' preference to borrow in foreign currency as opposed to in local currency, due to the appreciation of the local currency. As a result loan commitments in terms of local currency decreases with an appreciating local currency. Honig [15] also supports this notion and argues that with stable foreign currency rates, borrowers will choose to borrow in USD terms rather than in local currency. (One question that we are not able to answer with our dataset is the foreign currency loans for households and for corporations. One easy way to see this is to observe the behavior of FC loans after the regulatory change. Remember that the law prohibited only household FC loans; thus, if we find a small decrease in the current levels of FC loans, it can be an indicator that households constitute a small 
fraction of the overall FC borrowing. There was a drop of 11.3 billion TL in the level of FC loans in the second quarter of 2009 and another drop of 0.6 billion TL in the third quarter of 2009. However, the loan amounts reach their pre-regulation levels in the first quarter of 2010. Apparently, consumer loans were not a great portion of the overall loan portfolio.)

\subsection{The Stock Market}

The stock market also gives us an idea about the general economic performance and investor sentiment. Figure 8 shows the USD-based Istanbul Stock Exchange (ISE) 100 index during the study period. The market lost almost half of its value in 2008 as a result of the Global Financial Crisis; the index dropped from $\$ 2,789$ at the end of 2007 to $\$ 1,027$ at the end of 2008. The subsequent rise in the dollar-lira exchange rate can be seen in the same figure. The correlation between the returns on the stock market and the FX rate during the sample period is -0.71 . This suggests that the foreign currency exchange rate is highly correlated by stock market movements. The results of the pairwise Granger Causality Tests also confirm our findings. As shown in Table 2 while lira-dollar exchange rate movements do not Granger-cause ISE100 Index changes, the ISE100 level Granger causes the lira-dollar exchange rate. For example, the lira-dollar exchange rate jumped from 1.2 liras to a dollar to 1.7 when the ISE index dropped from $\$ 2,789$ at the end of 2007 to $\$ 1,027$ at the end of 2008 . The coefficient of correlation between the two variables is even higher during these crisis periods; during the 2006 emerging markets sell-off, we observed a correlation coefficient of -0.98 between March and June of 2006; while in 2008, the same value is -0.95 between 15 September 2008 (the Lehman Brothers Bankruptcy), and March 10, 2009 (the date considered to be the end of the bear market on Wall Street, when both Citibank and Bank of America announced positive earnings).

Figure 8. Istanbul Stock Exchange (ISE)100 USD-based index.

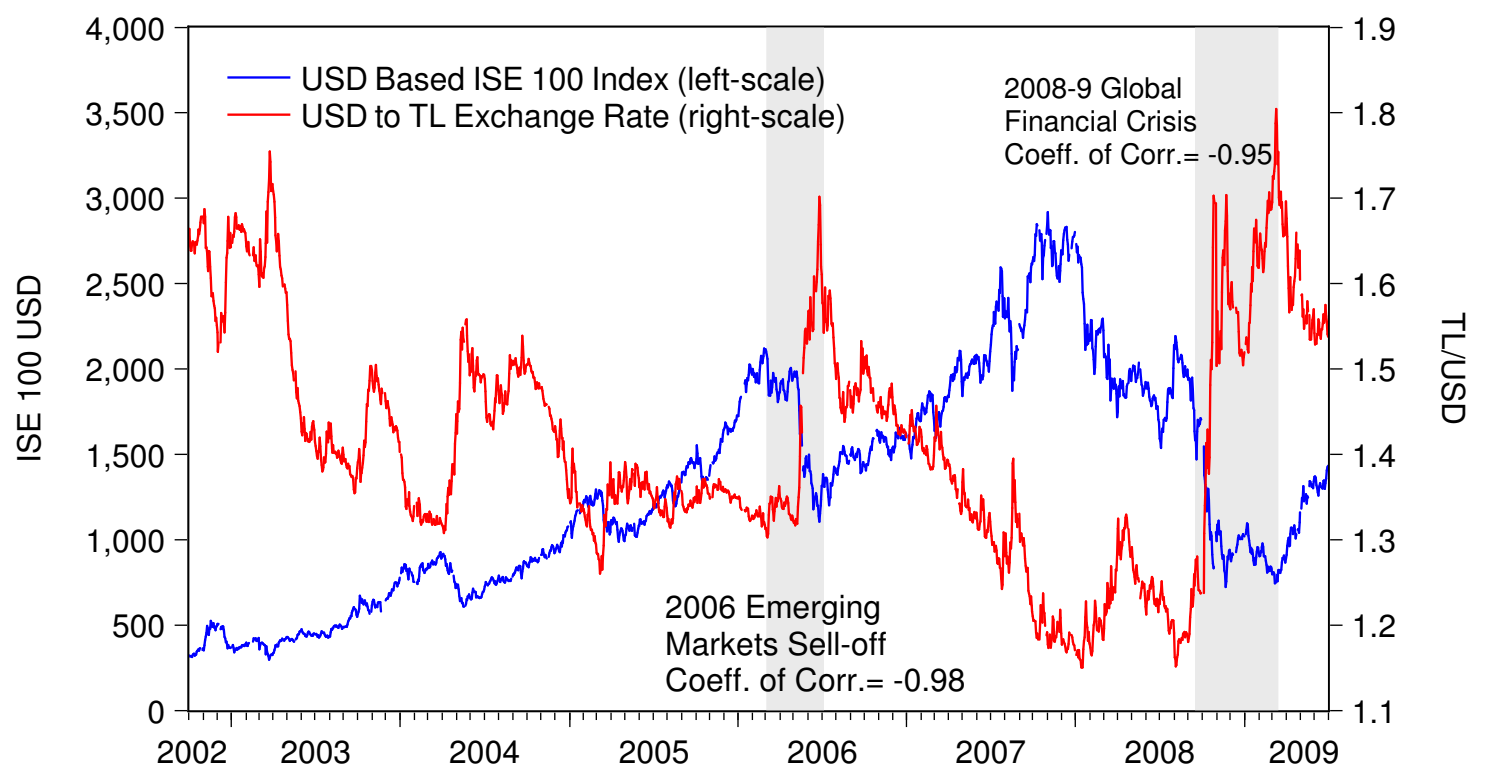

The figure shows the daily closing values of the USD-based Istanbul Stock Exchange ISE 100 Index for the study period and the Central Bank of the Republic of Turkey's (CBRT) daily USD buying rates. Exchange rates prior to January 1, 2005, have been reduced by one million to reflect the elimination of the six zeros at the end of the currency. Source: Istanbul Stock Exchange and the Central Bank of the Republic of Turkey. 
Table 2. Granger causality test results.

\begin{tabular}{lccc}
\hline Null Hypothesis & Observations & F-Statistic & Probability \\
\hline Lira-dollar FXrate does not Granger Cause ISE 100 & 1597 & 1.068 & 0.343 \\
ISE100 does not Granger-cause the lira-dollar FX rate & 1597 & 759.101 & 0.000 \\
\hline
\end{tabular}

This Table shows the results of the pairwise Granger causality tests between the Turkish lira-US Dollar exchange rate and the ISE 100 level. The number of lags included is two.

\subsection{Banks Liquidity Management and Monetary Policy}

Figure 9 shows that we can see the ratio of aggregate loans to aggregate deposits, both in foreign currency. This ratio gives us an understanding about the recycling rate of foreign currency deposits to foreign currency loans. There is a clear increasing trend during the 2002-2009 period with respect to this ratio: it increases from 0.38 in 2002 to almost 0.67 in the first quarter of 2009.

Figure 9. FC loans to FC deposits ratio.

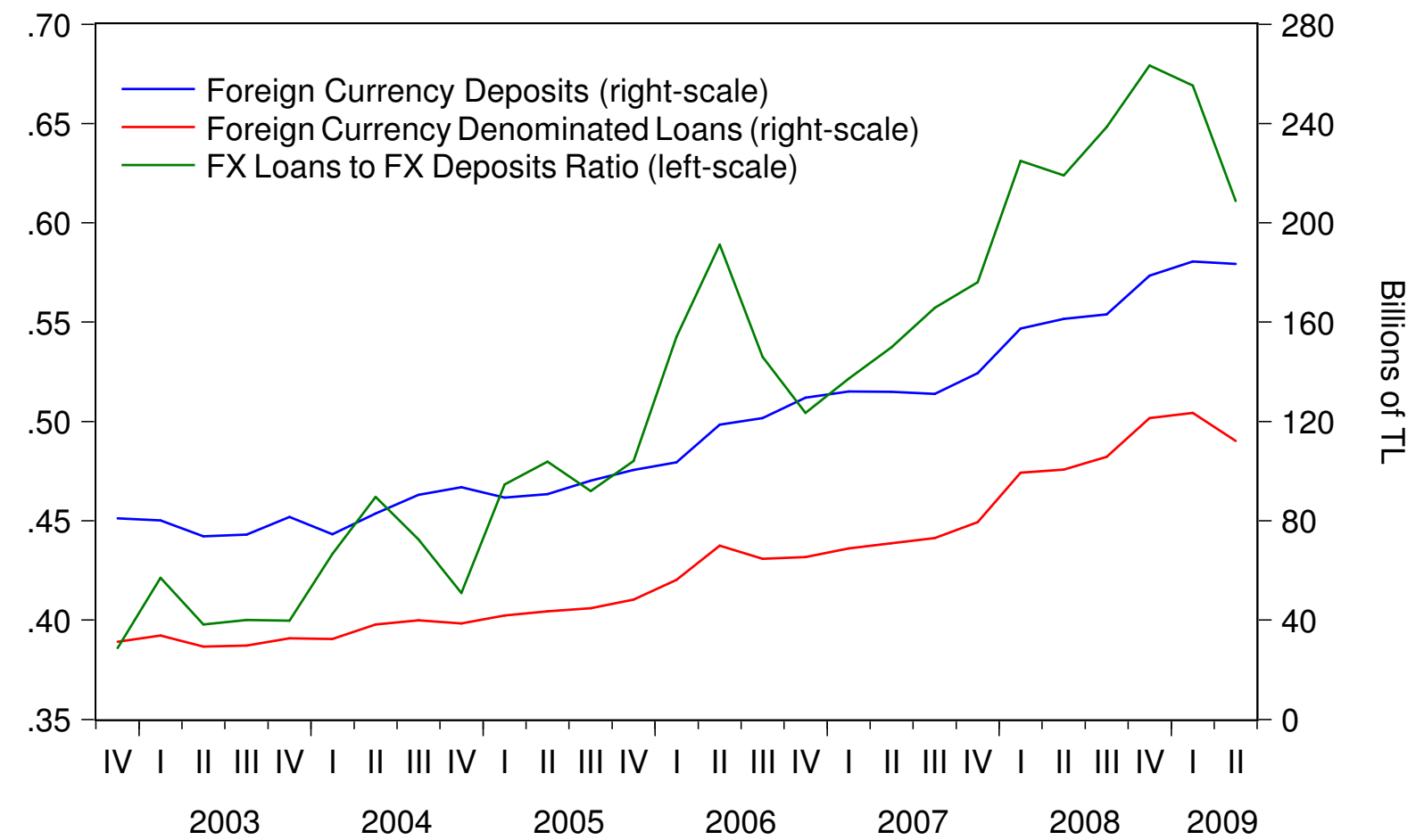

The figure shows the ratio of foreign currency loans (loans $f$ ) ) to foreign currency deposits (ddepfc) extended by the banks in our sample for the 2002-2009 period.

There are two ways to read this trend: either foreign currency loans increased with respect to foreign currency deposits or foreign currency deposits decreased with respect to foreign currency loans. We had seen in the previous section that it is more likely the first scenario, since the level of foreign currency deposits remain stable throughout the study period, while foreign currency loan amounts increased continually. Figure 10 gives us a more clear picture with respect to this situation. We can observe from Panel 1 of the figure that the deposits in Turkish liras did not catch up with the demand for loans 
in local currency (observe in Panel 1 that the distance between TL deposits and TL loans decreases, arriving at its minimum at around 2008). This was not the case for the relationship between FC deposits and FC loans, which maintained a ratio of (loansfc/depfc) of around 0.7 during the same period.

The increasing demand for loans in foreign currency have another implication: this should have increased banks' efforts to supply foreign currency through various means. In other words, Turkish banks should have increased their efforts to source foreign currency funds during this period. Indeed, Turkish banks engaged in all or any combination of the following strategies aimed at sourcing foreign currency during this period:

- Issue dollar denominated securities - securitization (since 2004 Turkish, banks have successfully sold US Dollar or Euro denominated trade-finance or credit-card based securities in international markets),

- borrow from foreign banks and,

- attract more FC deposits.

When we evaluate the balance sheets and off-balance sheet commitments of the 21 Turkish banks in our dataset, we find that Turkish banks increased their securitization activity in foreign markets: of the 21 banks in our sample, 14 have successfully issued securities mostly for trade receivables in international markets. The total securitization activity by the banks in our sample increased from 887 million TL (624 million USD) in 2004 to over 6.4 billion TL (4.7 billion USD) in 2005 and to 5.6 billion TL (3.9 billion USD) in 2006.

The banks also increased their borrowing from international markets in addition to securitization. The third panel in Figure 10 shows the progression of Turkish banks' foreign borrowing activity against the FX rate. We can clearly see that foreign borrowing and the changes in the exchange rates (TL per USD) are related.

In the second panel of the same Figure, we show banks' liquidity positions (measured by the difference between deposits and loans) in foreign currency and in Turkish liras against their foreign borrowing. As can be seen, after 2006, TL liquidity falls significantly, and the amount of borrowing from foreign banks increases. However, liquidity in foreign currency increases during the same period. 
Figure 10. FC and TL liquidity and banks' foreign borrowing activity.
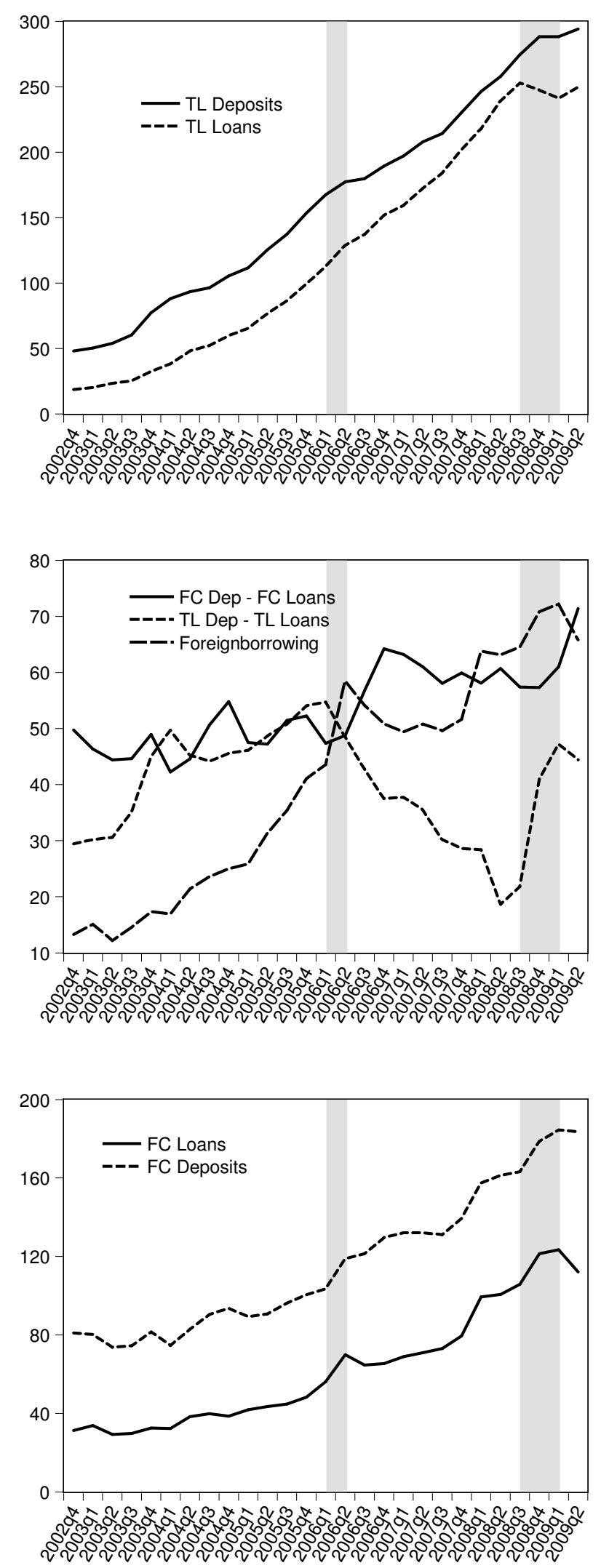

In the figure above, Panel 1 shows the level of banks' deposits in Turkish liras vs. their loans in Turkish liras (a measure we call their "TL liquidity"); Panel 2 illustrates banks' foreign borrowing versus their liquidity in Turkish liras (TL liquidity) and in foreign currency (measured by the difference between FC deposits and FC loans); Panel 3 illustrates banks' liquidity in foreign currency. All figures are in billions of Turkish liras. The shaded areas represent the following periods: the 2006 emerging markets sell-off (3/1/2006-6/30/2006) and the 2008 Global Financial Crisis (9/15/2008-3/10/2009). 


\subsection{Monetary Policies of the Central Bank}

In conjunction with the ITregime, the Turkish Central Bank consistently lowered the levels and the spread between the overnight borrowing and lending rates during the 2002 and 2009 period. At the end of 2002, the Central Bank's benchmark borrowing (lending) rate was 44\% (51\%), and by the end of 2008 , the same rates were $15 \%(17.5 \%$ ), which implies that the spread decreased from $7 \%$ to $2.5 \%$ (a 64\% decrease). This dynamic shows the commitment of the Turkish monetary authorities to provide the liquidity that was required by its growing economy and their mandate to keep the inflation target in line. Figure 11 illustrates the rate changes.

Figure 11. CBRT's monetary policy rates.

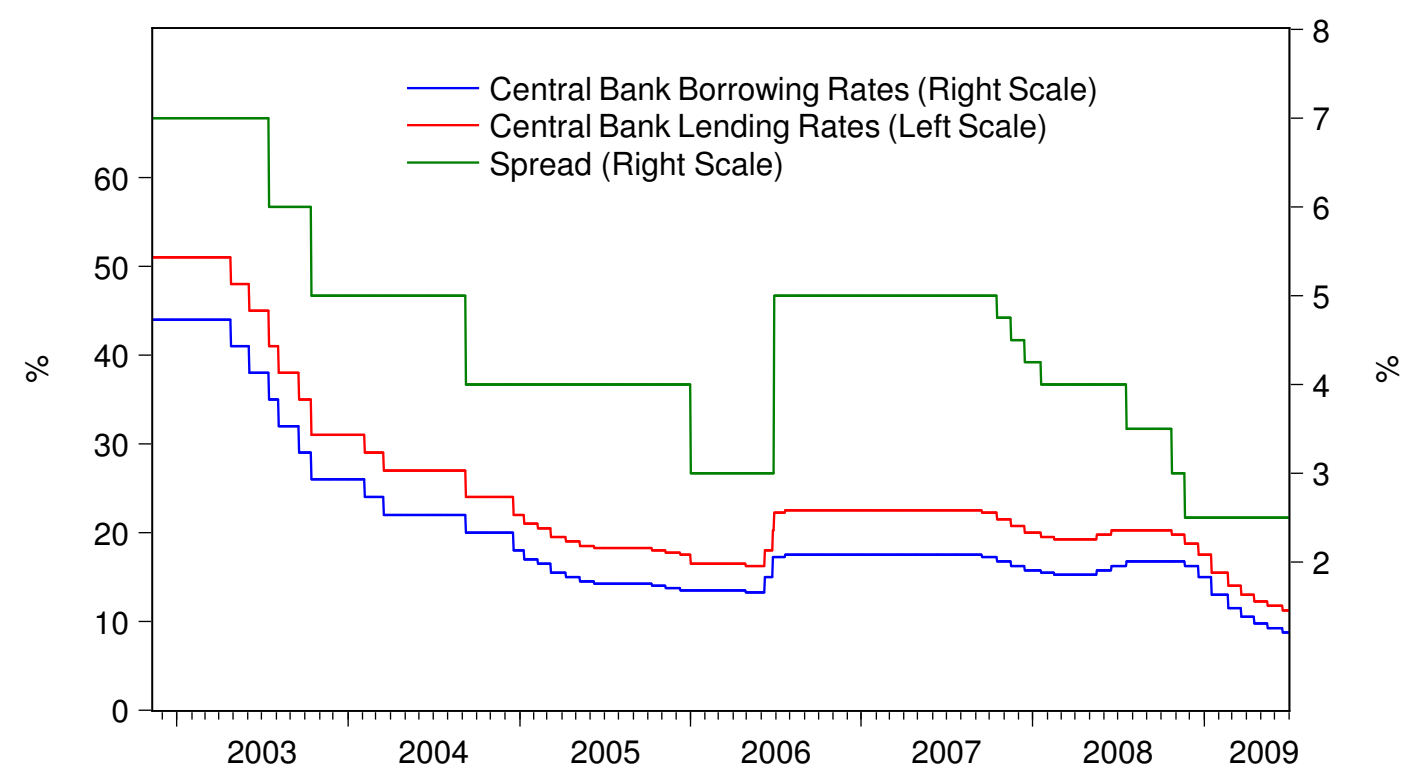

The figure shows the lending and borrowing rates by the Central Bank of the Republic of Turkey (CBRT), as well as the spread between the lending and borrowing rates between 2002, Q4, and 2009, Q2. All figures are in terms of percentages. Source: CBRT.

\section{Conclusions}

Dollarization is heavily related to inflation, as argued by the currency substitution view. This theory argues that as inflation goes up, so does the degree of deposit and loan dollarization in an economy. Another implication of the view is when inflation falls, households and businesses should switch back to local currency for their savings and borrowing needs. The currency substitution view partially explains the fall in the overall degree of dollarization in Turkey following the adoption of the inflation targeting regime and the subsequent fall in the annual inflation rate. Other factors may also contribute to dollarization. As suggested by the institutional view and the Minimum Variance Portfolio Theory, the institutional credibility or the relative volatility of inflation and the real exchange rate depreciation are also known to be other drivers of the dollarization process. Thus, stabilization of the inflation rate may or may not necessarily lead to de-dollarization of a banking system.

In the case of Turkey, during our analysis period, we see that there is a high correlation between inflation and the ratio of foreign currency loans to local currency loans. The Turkish banking system 
simply converts foreign currency deposits into foreign currency loans, as we find out. The absence of hedging as a result of such practice makes the Turkish banking system vulnerable to sudden and drastic exchange rate fluctuations. We know from history that global economic crises lead to the outflow of capital from emerging market economies like Turkey and can result in large and sudden depreciation of local currency. Considering the fact that by 2009 , more than a quarter of all loans in the Turkish banking system were in the form of foreign currency and for every $10 \mathrm{TL}$ worth of foreign currency deposit in the system, there is $7 \mathrm{TL}$ worth of FC loans, we can understand the severity of the risk posed. The timing of the 2009 decision is appropriate given the increase in the foreign currency loans vis--vis foreign currency deposits in the banking system. We believe the regulators in Turkey made the policy change as a preventive measure against possible future financial distress, which might have undesirable social implications. By only concentrating on household loans as opposed to business loans, the regulators also aimed at protecting the group of borrowers who are more prone to financial losses.

In the aftermath of the regulatory change, Turkish banks continued to lend in foreign currency to mainly export-oriented industries. In a report released by the S\&Pin 2012, it is mentioned that about one-third of commercial loans at that time are denominated in foreign currencies, and because the banking system is prohibited from lending to households in foreign currencies, its exchange rate risk is not significant [16]. In October, 2013, the Turkish Central Bank issued another decision regarding foreign currency deposit accounts. All existing foreign currency accounts were to be ceased or converted to Turkish lira accounts by 2015. This new development shows the willingness on the part of Turkish regulatory authorities to restrict foreign currency exposure in the banking system even further [17].

We believe our conclusions here can be generalized to other heavily dollarized economies. Regulatory changes regarding loan dollarization, as in the Ukraine, Croatia, Kazakhstan, Romania, South Korea, Angola, Belarus and Serbia, are moving towards the mitigation of the risks explained above. Thus, our findings in the case of Turkey can be applicable to other such economies in the world.

\section{Acknowledgments}

The authors would like to thank Dominick Salvatore of Fordham University, Ali Kutan of Southern Illinois University at Edwardsville, Scott Stoddard of SUNY-Fashion Institute of Technology and Ahmet F. Aysan of the Central Bank of Turkey for their valuable comments, support and help in the writing of this paper.

\section{Conflicts of Interest}

The authors declare no conflict of interest.

\section{References}

1. Brown, M.; Haas, R.D. Foreign currency lending in emerging Europe: Bank-level evidence. Econ. Policy 2012, 27, pp. 57-98. 
2. Calvo, G.; Vegh, C. From Currency Substitution to Dollarization and Beyond: Analytical and Policy Issues. In Essays on Money, Inflation, and Output; Calvo, G., Ed.; MIT Press: Cambridge, MA, USA, 1997.

3. Savastano, M. Dollarization in Latin America-Recent Evidence and Some Policy Issues. In The Macroeconomics of International Currencies; Mizen, P., Pentecost, E., Eds.; Edward Elgar Publishing: Cheltenham, UK, 1996.

4. Giovannini, A.; Turtelboom, B. The Handbook of International Macroeconomics; Blackwell Publishers: Hoboken, NJ, USA, 1994; Chapter Currency Substitution, pp. 390-436.

5. Levy-Yeyati, E. Financial Dollarization: Evaluating the Consequences. Econ. Policy 2006, 21, 61-118.

6. Ize, A.; Levy-Yeyati, E. Financial dollarization. J. Int. Econ. 2003, 59, 323-347.

7. Basso, H.S.; Calvo-Gonzalez, O.; Jurgilas, M. Financial dollarization: The role of foreign-owned banks and interest rates. J. Bank. Financ. 2011, 35, 794-806.

8. Neanidis, K.C.; Savva, C.S. Financial dollarization: Short-run determinants in transition economies. J. Bank. Financ. 2009, 33, 1860-1873.

9. De Nicolo, G.; Honohan, P.; Ize, A. Dollarization of bank deposits: Causes and consequences. J. Bank. Financ. 2005, 29, 1697-1727.

10. Calvo, G. On dollarization. Econ. Transit. 2002, 10, 393-403.

11. Luca, A.; Petrova, I. What drives credit dollarization in transition economies? J. Bank. Financ. 2008, 32, 858-869.

12. Ozsoz, E. Evaluating the effects of deposit dollarization in financial intermediation in transition economies. East. Eur. Econ. 2009, 47, 5-24.

13. Kutan, A.M.; Ozsoz, E.; Rengifo, E.W. Cross-sectional determinants of bank performance under deposit dollarization in emerging markets. Emerg. Markets Rev. 2012, 13, 478-492.

14. Setser, B.; Allen, M.; Keller, C.; Rosenberg, C.B.; Roubini, N. A Balance Sheet Approach to Financial Crisis. IMF Working Papers 02/210, International Monetary Fund, 2002. Online resources: International Monetary Fund. Available online: http://www.imf.org/external/pubs/cat/longres.cfm?sk=16167.0 (accessed on 1 November 2013).

15. Honig, A. Dollarization, exchange rate regimes and government quality. J. Int. Money Financ. 2009, 28, 198-214.

16. Standard and Poors. Banking Industry Country Risk Assessment: Turkey; Technical Report; S\&P Sovereign Ratings, Standard and Poors Ratings: New York, NY, USA 2012.

17. Turkey, C. Super Doviz Hesaplari Kalkiyor. News Report, CNBCe.com, 2013, (In Turkish). Available online: http://www.cnbce.com/haberler/finans/super-doviz-hesaplari-kaldiriliyor (accessed on 1 November 2013).

(C) 2013 by the authors; licensee MDPI, Basel, Switzerland. This article is an open access article distributed under the terms and conditions of the Creative Commons Attribution license (http://creativecommons.org/licenses/by/3.0/). 